\title{
Predicting Student Achievement through Organizational Learning Culture
}

\author{
Muhammad Akram * Ashfaque Ahmad Shah ${ }^{\dagger}$
}

\begin{abstract}
This study focused on investigating the impact of learning culture on student achievement in Pakistani public high schools. An Urdu version of the Dimensions of a Learning Organization Questionnaire (DLOQ) was administered to head teachers of 174 public boys and girls high schools selected through random sampling technique. The overall percentage scores of the sampled high school in the Board of Intermediate and Secondary Education Lahore annual examination 2016 were also collected from the head teachers. The results showed that the seven factors of the DLOQ were significantly positively correlated with each other. The Simple linear regression analysis revealed that the seven dimensions of the DLOQ significantly predicted student overall achievement in Lahore Board Examination. A multiple regression analysis revealed that head teacher's empowerment and strategic leadership explained 22 percent of the variance in student achievement. The limitations of the study include smaller sample size of head teachers, and private tuition most of the students take throughout the year.
\end{abstract}

Keywords: Learning culture, strategic leadership, embedded learning, student achievement, empowerment.

\section{Introduction}

Taking school as a learning organization is vital to provide teachers opportunity to share professional knowledge, work collaboratively, and learn how to meet organizational challenges (Watkins \& Marsick, 1996). A school is a learning place which continually expands its creating capacity and where teachers work, individually as well as in teams, at varying levels and expand their knowledge (Senge, 1990; Watkins, Milton, \& Kurz, 2009). The learning culture in a school facilitates teachers' performance, increases efficiency and effectiveness (Usman, Danish, Waheed, \& Tayyeb, 2011), and promotes skills and abilities of the individuals (Jamali \& Sidani, 2008)Jamali \& Yusuf, 2009). The learning culture of schools also helps teachers to continuously learn, promote dialogue, work in collaboration, thus feel empowered (Marsick \& Watkins, 2003).

Bates and Khasawneh (2005) are of the view that learning environment gives confidence and inspiration to the learners for further improvement in the organizations. Senge (1990) stated that organizations with sound learning culture constantly increase the working abilities of their workers to get better results by utilizing their skills and energies to

\footnotetext{
*Assistant Professor, Division of Education, University of Education, Lahore, Pakistan.

E-mail: makram@ue.edu.pk

${ }^{\dagger}$ Centre for Economics of Education, Department of Education, University of Sargodha, 40100, Sargodha, Pakistan.

E-mail: multanxa@gmail.com
} 
the maximum level. Garvin (2003) found that if learning culture is not developed then persons and organizations only repeat their old methods to do their work. Watkins and Marsick (1996) agree that learning in organizations is very beneficial which expands the knowledge of the learners by generating and altering their personal authenticity in the shape of fresh knowledge.

Watkins and Marsick (1996) and Wood (2007) are of the view that the questioning and dialogue permit the organizations to create a comfortable atmosphere, promote their civilization, and construct the vision in this perspective. According to Dewey (2013), learners improve and develop their thinking, problem solving abilities, and understandings of realities through inquiry and dialogue. This is a kind of intellect and aptitude of sharing the thoughts with others for the reproduction of refined thoughts.

Organizations frequently strive for becoming learning organizations. In learning organizations, the individuals share their knowledge with each other which results in promoting group learning (Marsick \& Watkins, 2003). Senge (1990) stated that organizations with sound learning culture constantly increase the working abilities of their workers to get better results by utilizing their skills and energies to the maximum level. Watkins and Marsick (1996) are of the view that learning is a continuous and organized process through which the learners decide to take part in the organizational activities to adjust themselves in a stable society. Garvin (2003) examined that the learning environment affects the achievements of the learners by inspiring them to get new ideas and information. The researcher thus stresses upon the idea that it is very essential for the organization to provide suitable learning culture for active learning.

The research tells that learning organizations are vital to improve organizational performance. Various researches employed DLOQ and provide evidence of positive relationship of learning culture with organizational performance (Akhtar, Arif, Rubi, \& Naveed, 2011; Imran, Rizvi, \& Ali, 2011), leadership (Heck \& Hallinger, 2010; Jokar, Miri, \& Sabzikaran, 2012; Louis, Dretzke, \& Wahlstrom, 2010), quality management (Sisnuhadi \& Nasir, 2013), demographic variables (Pimapunsri, 2008; Watkins \& Marsick, 1993), feedback and job role (Usman et al., 2011), Job satisfaction (Sempane, Rieger, \& Roodt, 2002; Zhang \& Li, 2013) motivation to learn and job attitudes (Malik, Danish, \& Usman, 2011), and head teachers inclination toward involving teachers in decision making (system connections) (Taylor \& Bogotch, 1994).

Watkins and Marsick (1996) developed DLOQ which has been extensively used in various public and private organizations. Watkins and Marsick described that in learning organizations, continuous learning opportunities are provided to the employees, team members work collaboratively, promote dialogue and inquiry, promote embedded learning, and the employees of such organizations feel empowered. In System Connections, employees feel balance between their work and family. Further, team leaders are able to demonstrate leadership roles to implement innovative school reform.

Since the ultimate goal of the teaching and learning process is increasing student achievementdue to the increased teacher accountabilitythe researchers were interested in measuring the impact of organizational learning culture on student achievement scores. If a principal is able to create a learning culture within the school through increasing dialogue and inquiry among teachers, empowering them, and sharing their knowledge, 
student achievement might be increased which ultimately helps the principals as well the teachers to meet the accountability standards. Little has been explored about the learning culture in public schools (Akram, Watkins, \& Sajid, 2013). One study found positive impact of teacher empowerment on student achievement (Marks \& Louis, 1997). Perhaps there has not been explored the impact and/or relationship between a learning culture of the schools and student achievement, especially in Pakistan. This study aims to fill this gap through using the DLOQ in Pakistani public schools and exploring the impact of learning culture on student achievement.

\section{Research Questions}

1. What is the relationship among the dimensions of a learning culture in Pakistani public schools?

2. What is the relationship between learning culture dimensions and student overall achievement in Pakistani public schools?

3. To what extent do the dimensions of learning culture (individually) predict student overall achievement in the BISE Examinations?

4. To what extent do the dimensions of learning culture combine to predict student achievement in the BISE Examinations?

\section{Literature Review}

Learning culture plays an important role in teaching learning process. Bates and Khasawneh (2005) stated that organization Learning maximizes sharing of information. Marsick and Watkins (2003) found that organizational learning culture is very important for the growth of an organization. Various studies have shown significant contribution of learning culture of an organization to the performance of their employees. Imran et al. (2011) conducted correlational study to find out the relationship of learning culture of banks with the performance of their 110 employees. This study found that empowerment and continuous learning were the strongest predictors of employees' success. Watkins et al. (2009) measured the effect of learning culture on employees' performance in health sector and found significant relationships between the indicators of learning culture and the performance of employees at the individual, team, and organizational levels.

Various other researchers found some of the important studies that showed considerable relationship and effect of learning culture on student achievement. For example, Hofman, Hofman, and Guldemond (2002) investigated the relationship between school governance, school culture, and student achievement in public and private schools. The multivariate analysis revealed that $34 \%$ of the mathematics achievement of pupils could be explained through social contexts of learning. Quin, Deris, Bischoff, and Johnson (2015) investigated the correlation between leadership, culture, and student achievement in elementary, middle, and high schools. 216 teachers from 31 schools were selected as a sample 
of the study. Learning culture demonstrated significant positive relationship with student achievement.

Rhoden (2012) conducted an ex-post facto study and found that student achievement was significantly correlated with head teachers' leadership behavior and school climate. 58 participants responded to the online questionnaires. Multiple linear regressions were used to determine the extent to which student achievement could be predicted though leadership behavior and school climate. A marginally significant relationship was found between school climate and student achievement at high school level.

Vislocky (2005), for example, explored the relationship between school culture and student achievement in a middle school in Florida. Data were collected from the six middle schools using a learning culture questionnaire. The study found the significant positive relationship between students' score on learning culture and their achievement in reading score in different grades. Another study of Swindler (2009) found that the relationship between learning culture and student performance were non-significant.

One of the significant studies on measuring the effect of learning culture on student achievement was conducted by MacNeil, Prater, and Busch (2009). The authors of this study found that students who achieved higher scores on standardized tests in schools demonstrated higher score on learning environments. Boyer (2012) conducted a study to find out the relationship between servant leadership, school culture, and student achievement in Lower Kuskokwim School District, USA. The results of the study demonstrated no positive significant relationship between school culture and student achievement.

Bai and Fallah (2012) found significant positive correlation between the indicators of learning organization culture and the performance of players in sports. Akram et al. (2013) conducted preliminary study on comparing the learning culture of high and low performing boys and girls secondary schools in Pakistan using the DLOQ; this study found that high performing schools demonstrated higher level of learning culture and the vice versa. Bates and Khasawneh (2005) found significant relationships between organizational learning culture, learning transfer climate and organizational innovation in Jordan. Similar results were found by Bektas, Çogaltay, Karadag, and Ay (2015).

Koçyiğit (2017) examined the effects of school culture on student achievement in Turkey. Using a meta-analysis approach, the researcher selected 303 studies for literature review. Out of them, 71 studies were found appropriate for the study. Based on these studies, the researcher found a significant impact (0.49) of school culture on student achievement. The findings of the meta-analysis composed of the previous literature on the said topic.

Various other studies fund mixed results of the relationships student achievement and continuous learning (Akram et al., 2013; DuFour \& Eaker, 2009; Vescio, Ross, \& Adams, 2008), dialogue and inquiry (Timperley, Wilson, Barrar, \& Fung, 2008) embedded learning (Darling-Hammond \& Richardson, 2009), (Saye \& Brush, 2001) teacher empowerment (Goddard, Goddard, \& Tschannen-Moran, 2007; Marks \& Louis, 1999), and leadership (Louis et al., 2010).

The above literature shows mixed results of the relationship and impact of learning culture with and on student achievement. The research has not been able to find any study on predicting student success through learning culture of school. This study is an endeavor to fill this gap and find out the impact of learning culture on student achieve- 
ment.

\section{Theoretical Framework}

This study has been framed on the model of the learning organization of Watkins and Marsick (1993). Figure 1 depicts the connection between the dimensions of the construct.

Figure 1

Watkins and Marsick (1993)'s model of dimensions of a learning organization

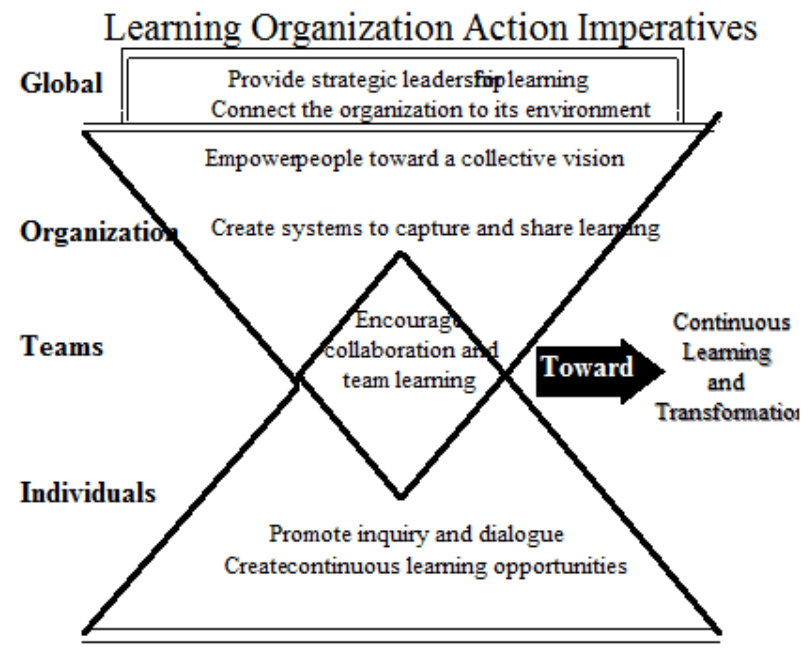

The model of Watkins and Marsick (1993) has been extensively used by various researchers across the subcontinents for measuring learning culture of the organizations. This model includes seven dimensions namely Creating continuous learning, Promoting inquiry and dialogue, Team learning, embedded systems, empowerment, System Connections, and Leadership roles. Based on this theoretical framework, the research anticipated that student achievement could be predicted by the dimensions of the learning culture. These dimensions work at individual, group and organization levels.

Learning organizations provide continuous learning opportunities to the employees who modify their thinking and working approaches and create connections between the colleagues. Such modifications help individuals and teams to transform their deeper understanding into purposeful and meaningful activities. The dimensions of promoting inquiry and dialogue focuses on promoting environment that is conducive to learning and where continuous feedback strengthens interpersonal relationships and respectful communication.

Team learning also focuses on sharing ideas and vision for bringing harmony between organizational goals and individual goals. While working in teams, individuals share their knowledge and skills with others and help others to delineate their problems and 
get benefits form others experiences. Embedded systems concentrate on providing people work choice and take initiatives. Collaboration is the key to this dimension which leads to continuous improvement in performance.

Empowerment provides individuals such as teachers to demonstrate higher level of job satisfaction, a sense of belongingness, and an authority that makes them to take more interest toward successful completion of the organizational tasks. The dimension of Leadership is one of the strong predictors of organizational success. In the learning organizations, the individuals are provided with ample opportunities of leading to others by demonstrating their vision and skills and helping other to grow and take further leadership roles.

\section{Methodology}

This correlational study involved 43 scale items survey to measure head teachers' perspectives of learning culture. One hundred and seventy four $(\mathrm{N}=174)$ headmasters or headmistresses from District Lahore and Okara were selected through simple random sampling technique. The list of these headmasters and headmistresses was taken from the District Education Office, Lahore. An Urdu version of the Dimensions of Learning Organization Questionnaire (Akram et al., 2013) was used to investigate the relationship among dimensions of a learning culture and their relationship with student achievement. The Urdu version of the DLOQ was translated based on the original DLOQ developed by Watkins and Marsick (1996). The DLOQ has been extensively used around the globe and more than 70 studies have been conducted based on this questionnaire. The reliability of the DLOQ has been established in different countries and in different languages during the last two decades. The measurement levels of the scale ranged from Almost Never (1) to Almost Always (6). The DLOQ involves 7 dimensions named Continuous Learning, Dialogue Inquiry, Collaboration Team Learning, Embedded Learning, Empower People, System Connections, and Strategic Leadership. The overall reliability of the DLOQ was measure as very high $(\alpha=.94)$; the reliability of the seven dimensions ranged from .82 to .89. Besides the DLOQ scores, the overall school results in percentage form were used as another measure for this study. The DLOQ along with consent form was mailed to the official addresses of these heads. Out of them, one hundred and seventy four returned the questionnaires and consent form in completed form. The response rate was $95 \%$. Further, overall school results on Lahore Board examination 2016 in10th grade were also obtained from the head of the schools. SPSS 20 was used to analyze the results.

\section{Results}

Descriptive statistics show that Strategic Leadership was found to be the most important dimension $(\mathrm{M}=4.80, \mathrm{SD}=.86)$, followed by System Connections $(\mathrm{M}=4.73, \mathrm{SD}=.85)$ and Collaborative Team Learning $(\mathrm{M}=4.73, \mathrm{SD}=.89)$. The least mean score was found in Continuous Learning dimension $(\mathrm{M}=4.28, \mathrm{SD}=.87)$. Summary of the descriptive statistics along with Cronbach Alpha reliability $(\alpha)$ of the dimensions is given in Table 1. 
Table 1

Descriptive Statistics of the Dimensions of Learning

Culture

\begin{tabular}{lccc}
\hline Dimensions & Mean & SD & $\alpha$ \\
\hline Continuous Learning (CL) & 4.28 & 0.873 & 0.815 \\
Dialogue \& Inquiry (D\&I) & 4.46 & 0.827 & 0.812 \\
Team Learning (TL) & 4.73 & 0.892 & 0.859 \\
Embedded Learning (EL) & 4.52 & 0.912 & 0.842 \\
Empower People (EP) & 4.68 & 0.834 & 0.856 \\
System Connections (SC) & 4.73 & 0.848 & 0.848 \\
Strategic Leadership (SL) & 4.80 & 0.863 & 0.885 \\
\hline
\end{tabular}

Pearson correlation analysis was conducted to examine the relationship among dimensions of learning culture. According to Table 2 (see below), all the seven dimensions of the DLOQ significantly positively correlated with each other. The strongest positive correlation was found between Empower People and System Connection dimensions $(\mathrm{r}=$ $.77, \mathrm{p}>.01)$, followed by Embedded Learning and Empower People dimensions $(\mathrm{r}=.76$, $\mathrm{p}>.01)$. The lowest correlation was found between Dialogue and Inquiry, and Strategic Leadership $(\mathrm{r}=.54, \mathrm{p}>.01)$.

Table 2

Relationship among Dimensions of Learning Organization Culture

\begin{tabular}{lcccccc}
\hline & CL & D\&I & TL & EL & EP & SC \\
\hline Continuous Learning (CL) & & & & & & \\
Dialogue \& Inquiry (D\&I) & $0.72^{*}$ & & & & & \\
Team Learning (TL) & $0.69^{*}$ & $0.72^{*}$ & & & & \\
Embedded Learning (EL) & $0.60^{*}$ & $0.60^{*}$ & $0.70^{*}$ & & & \\
Empower People (EP) & $0.60^{*}$ & $0.58^{*}$ & $0.71^{*}$ & $0.76^{*}$ & & \\
System Connections (SC) & $0.57^{*}$ & $0.55^{*}$ & $0.66^{*}$ & $0.72^{*}$ & $0.77^{*}$ & \\
Strategic Leadership (SL) & $0.57^{*}$ & $0.54^{*}$ & $0.63^{*}$ & $0.62^{*}$ & $0.65^{*}$ & $0.71^{*}$ \\
\hline
\end{tabular}

Pearson correlation analysis was run to measure the relationship between dimensions of learning culture and student achievement. According to Table 3 , the highest correlation was found between empower and student achievement, $\mathrm{r}=.26, \mathrm{p}>.01$, followed by the correlation between Strategic Leadership and student achievement, $r=21, p>.01$. The summary results are given in Table 3.

\begin{tabular}{|c|c|}
\hline Dimensions & $\mathbf{r}$ \\
\hline Continuous Learning & 0.08 \\
\hline Dialogue Inquiry & 0.11 \\
\hline Collaboration Team Learning & 0.06 \\
\hline Embedded Learning & 0.06 \\
\hline Empower People & $0.26^{*}$ \\
\hline System Connections & 0.04 \\
\hline Strategic Leadership & $0.21^{*}$ \\
\hline
\end{tabular}

Regression analyses are important statistics to measure the impact of the independent 
variable on the dependent variables. For this purpose, initially the assumptions of regression analysis such as linearity, constant variance, and outliers were checked. The scatterplots showed that the data were scattered constantly and linear trend in each dimension could be seen. A couple of cases looked to be influential; however when calculating, the Cooks D values which were less than .30 showed that these outliers were not influential. So the researchers ran further analysis including all the cases.

Simple linear regression was run to investigate the extent to which the student achievement score could be predicted through each dimension. The results are given in Table 4.

\begin{tabular}{lccccc}
$\begin{array}{l}\text { Table 4 } \\
\text { Simple Linear Regression Analysis }\end{array}$ & $\alpha$ & SE & Beta & T & Sig. \\
\hline Factors & 1.464 & 1.418 & 0.081 & 1.033 & 0.303 \\
\hline Continuous Learning & 2.003 & 1.494 & 0.105 & 1.341 & 0.182 \\
Dialogue Inquiry & 1.036 & 1.39 & 0.058 & 0.745 & 0.457 \\
Collaboration Team Learning & 1.021 & 1.361 & 0.059 & 0.751 & 0.454 \\
Embedded Learning & 5.46 & 1.622 & 0.256 & 3.366 & $.001^{*}$ \\
Empower People & 0.822 & 1.464 & 0.044 & 0.562 & 0.575 \\
System Connections & 3.714 & 1.41 & 0.203 & 2.633 & $.009^{*}$ \\
Strategic Leadership & & & & &
\end{tabular}

The results found that Empower people significantly predicted student achievement, $(\mathrm{r}=0.256), \beta=5.460, \mathrm{t}(162)=3.366, \mathrm{p}>0.001$. The $R^{2}$ value revealed that empowering people predicted almost $5 \%$ of the variance in student achievement $F(1,172)=11.330$, $p$ $>0.00$. The study further found that Strategic Leadership significantly predicted student achievement, $(\mathrm{r}=0.203), \beta=3.714, \mathrm{t}(172)=2.633, \mathrm{p}>0.009$. The $\mathrm{R} 2$ value revealed that strategic leadership predicted almost $4 \%$ of the variance in student achievement $F(1,172)$ $=5.997, \mathrm{p}>0.00$. Other dimensions, however, did not significantly predicted student achievement.

A multiple linear regression was run to investigate the extent to which dimensions of a learning culture combine to predict student achievement. (See Table 5)

\begin{tabular}{lccccc}
$\begin{array}{l}\text { Table } 5 \\
\text { Multiple Regression Analysis }\end{array}$ & & & & \\
\hline \multicolumn{7}{l}{$\alpha$} & SE & Beta & T & Sig. \\
\hline (Const.) & 45.639 & 8.452 & & 5.400 & 0.000 \\
Strategic leadership & 4.264 & 2.094 & 0.233 & 2.036 & 0.043 \\
Empower People & 5.357 & 2.028 & 0.251 & 2.641 & 0.009 \\
\hline
\end{tabular}

The enter-method multiple regression model revealed that together, two predictors explained $22 \%$ variance in student achievement. Empower people $(\beta=.25)$ was found the strongest predictor, followed by Strategic Leadership $(\beta=.23)$. The findings show that both Empower people and Strategic leadership predicted student achievement positively. Tests for multicollinearity indicated that a moderate level of multicollinearity was present $(\mathrm{VIF}=3.36$ for strategic leadership, and 2.30 for empower people). 


\section{Discussion}

This study focused on predicting student achievement through the learning culture of the public high schools in Pakistan. The Dimensions of Learning Organization Culture (DLOQ) developed by Watkins and Marsick (1996) was used to measure the learning culture of 174 head teachers of male and female schools in Lahore. The overall percentage score of each sampled school was collected from the head teachers of these schools. The study found that there was a significant relationship between learning culture and student achievement. Further, the study explored that student achievement could be predicted through strategic leadership. The results of this study are aligned with the study of Jokar et al. (2012); Heck and Hallinger (2010); Louis et al. (2010); Marks and Louis (1997) in terms of strategic leadership. Another study of Zagoršek, Dimovski, and Škerlavaj (2009) also found that leaders encourage open and honest communication and foster dialogue and collaboration between team members, thus lead to improved performance and better learning culture.

Empowering teachers is very important dimension. When teachers feel empowered, they feel authorized, and perform according to their intrinsic motivation. The finding of this study is aligned with the previous studies (Goddard et al., 2007; Marks \& Louis, 1997, 1999; Marsick \& Watkins, 2003). Northouse (2018) stated that leaders motivate followers with trust and empowerment which is fundamental them to share their knowledge without the fear of becoming vulnerable.

This study demonstrated student achievement can be impacted through the strategic leadership and empowerment of teachers. If head teachers involve their teachers in decision making, empower them to help carry out the school's directions, mentors them, and continually look for opportunities to learn, they can motivate teachers toward rendering their services effectively, and, consequently can increase student achievement. Also, by sharing leadership related knowledge with their colleagues, head teachers can provide opportunity to the teachers to work collaboratively and take advantage of the knowledge and skills of their head teacher. The study indicates that head teachers are integral part of increasing student achievement, indirectly, through creating the learning culture within the organizations.

The study, however, involves a couple of precautions. One: the sample size was not quite large to generalize the results over all 35 districts of the province (Punjab). Secondly, it is not known how many students take private tuition that can increase student achievement. The authors, therefore, recommend that the results of this study might be generalized cautiously. Further studies might be conducted involving a larger number of sample size including head teachers of the rural and urban highs schools. 


\section{References}

Akhtar, S., Arif, A., Rubi, E., \& Naveed, S. (2011). Impact of organizational learning on organizational performance. International Journal of Academic Research, 3(5), 327-331.

Akram, M., Watkins, K. . E., \& Sajid, S. A. (2013). Comparing the learning culture of high and low performing high schools in Pakistan. Literacy Information and Computer Education Journal, 4(2), 1022-1028.

Bai, N., \& Fallah, Z. (2012). Relationship between learning culture and organizational performance in Iran's ministry of sports and youth. European Journal of Experimental Biology, 2(6), 2206-2211.

Bates, R., \& Khasawneh, S. (2005). Organizational learning culture, learning transfer climate and perceived innovation in Jordanian organizations. International Journal of Training and Development, 9(2), 96-109.

Bektas, F., Çogaltay, N., Karadag, E., \& Ay, Y. (2015). School culture and academic achievement of students: A meta-analysis study. The Anthropologist, 21(3), 482-488.

Boyer, D. P. (2012). A study of the relationship between the servant leader principal on school culture and student achievement in the lower Kuskokwim school district (Unpublished doctoral dissertation). Grand Canyon University, Arizona.

Darling-Hammond, L., \& Richardson, N. (2009). Research review / teacher learning: What matters. Educational Leadership, 66(5), 46-53.

Dewey, J. (2013). The sources of a science of education. New York: Horace Liveright.

DuFour, R., \& Eaker, R. (2009). Professional learning communities at work: Best practices for enhancing students achievement. Solution Tree Press.

Garvin, D. A. (2003). Learning in action: A guide to putting the learning organization to work. Harvard Business Review Press.

Goddard, Y. L., Goddard, R. D., \& Tschannen-Moran, M. (2007). A theoretical and empirical investigation of teacher collaboration for school improvement and student achievement in public elementary schools. Teachers College Record, 109(4), 877-896.

Heck, R. H., \& Hallinger, P. (2010). Collaborative leadership effects on school improvement: Integrating unidirectional- and reciprocal-effects models. The Elementary School Journal, 111(2), 226-252.

Hofman, R. H., Hofman, W. A., \& Guldemond, H. (2002). School governance, culture, and student achievement. International Journal of Leadership in Education, 5(3), 249-272.

Imran, M., Rizvi, S. H. M., \& Ali, B. (2011). Impact of organizational learning on organizational performance. International Journal of Academic Research, 3(4), 424-427.

Jamali, D., \& Sidani, Y. (2008). Learning organizations: Diagnosis and measurement in a developing country context: The case of Lebanon. The Learning Organization, 15(1), 58-74.

Jokar, A., Miri, A., \& Sabzikaran, E. (2012). Investigation of relationships between learning organization and transformational leadership in Iranian Civil Industries. Journal of American Science, 8(6), 738-744.

Koçyiğit, M. (2017). The effect of school culture on student achievement. In The factors effecting student achievement. Springer International Publishing. 
Louis, K. S., Dretzke, B., \& Wahlstrom, K. (2010). How does leadership affect student achievement? Results from a national US survey. School Effectiveness and School Improvement, 21(3), 315-336.

MacNeil, A. J., Prater, D. L., \& Busch, S. (2009). The effects of school culture and climate on student achievement. International Journal of Leadership in Education, 12(1), 73-84.

Malik, M. E., Danish, R. Q., \& Usman, A. (2011). Impact of motivation to learn and job attitudes on organizational learning culture in a public service organization of pakistan. African Journal of Business Management, 5(3), 844-854.

Marks, H. M., \& Louis, K. S. (1997). Does teacher empowerment affect the classroom? The implications of teacher empowerment for instructional practice and student academic performance. Educational Evaluation and Policy Analysis, 19(3), 245-275.

Marks, H. M., \& Louis, K. S. (1999). Teacher empowerment and the capacity for organizational learning. Educational Administration Quarterly, 35(5), 707-750.

Marsick, V. J., \& Watkins, K. E. (2003). Demonstrating the value of an organization's learning culture: The dimensions of the learning organization questionnaire. Advances in Developing Human Resources, 5(2), 132-151.

Northouse, P. G. (2018). Leadership: Theory and practice. Sage publications, Thousand Oaks, CA.

Pimapunsri, P. (2008). Factors affecting learning organization culture and hotel managers' leadership styles in Thailand. Education Journal of Thailand, 2(1), 34-43.

Quin, J., Deris, A., Bischoff, G., \& Johnson, J. T. (2015). Comparison of transformational leadership practices: Implications for school districts and principal preparation programs. Journal of Leadership Education, 14(3), 71-85.

Rhoden, V. (2012). The examination of the relationships among secondary principals' leadership behaviors, school climate, and student achievement in an urban context (Unpublished doctoral dissertation).

Saye, J., \& Brush, T. (2001). The use of embedded scaffolds with hypermedia-supported student-centered learning. Journal of Educational Multimedia and Hypermedia, 10(4), 333-356.

Sempane, M. E., Rieger, H. S., \& Roodt, G. (2002). Job satisfaction in relation to organisational culture. SA Journal of Industrial Psychology, 28(2), 23-30.

Senge, P. (1990). The fifth discipline: The art and science of the learning organization. New York: Currency Doubleday.

Sisnuhadi, \& Nasir, J. A. (2013). The role of organizational learning in the relationship between quality management practices and organizational performance. Interdisciplinary Journal of Contemporary Research in Business, 4(9), 72-92.

Swindler, N. H. (2009). Middle school cultures and student achievement (Unpublished doctoral dissertation). The University of Southern Mississippi.

Taylor, D. L., \& Bogotch, I. E. (1994). School-level effects of teachers' participation in decision making. Educational Evaluation and Policy Analysis, 16(3), 302-319.

Timperley, H., Wilson, A., Barrar, H., \& Fung, I. (2008). Teacher professional learning and development.

Usman, A., Danish, R. Q., Waheed, N., \& Tayyeb, U. (2011). Moderating effect of employees' education on relationship between feedback, job role innovation and organiza- 
tional learning culture. African Journal of Business Management, 5(5), 1684-1689.

Vescio, V., Ross, D., \& Adams, A. (2008). A review of research on the impact of professional learning communities on teaching practice and student learning. Teaching and Teacher Education, 24(1), 80-91.

Vislocky, K. (2005). The relationship between school culture and student achievement in middle schools (Unpublished doctoral dissertation). University of Central Florida.

Watkins, K. E., \& Marsick, V. J. (1993). Sculpting the learning organization: Lessons in the art and science of systemic change. Jossey-Bass, San Francisco.

Watkins, K. E., \& Marsick, V. k. (1996). In action: Creating the learning organization. Alexandria, VA: ASTD Press.

Watkins, K. E., Milton, J., \& Kurz, D. (2009). Diagnosing the learning culture in public health agencies. International Journal of Continuing Education \& Lifelong Learning, 2(1), 65-81.

Wood, D. R. (2007). Professional learning communities: Teachers, knowledge, and knowing. Theory into Practice, 46(4), 281-290.

Zagoršek, H., Dimovski, V., \& Škerlavaj, M. (2009). Transactional and transformational leadership impacts on organizational learning. Journal for East European Management Studies, 14(2), 144-165.

Zhang, X., \& Li, B. (2013). Organizational culture and employee satisfaction: An exploratory study. International Journal of Trade, Economics and Finance, 4(1), 48-54. 